Reprinted with permission from: Canadian Journal of Plant Science. April 1987.

67(2):509-510.

Published and copyrighted by: Agricultural Institute of Canada.

\title{
Glyphosate accumulation in leafy spurge laticifers $^{1}$
}

\author{
M. E. FOLEY
}

Department of Plant and Soil Science, Montana Agricultural Experiment Station, Montana State University, Bozeman, Montana, U.S.A. 59717-0002.

\begin{abstract}
:
In greenhouse experiments, ${ }^{14} \mathrm{C}$-glyphosate application to mature leafy spurge (Euphorbia esula L.) plants resulted in detectable radioactivity in the laticifer system 5 days after treatment.
\end{abstract}

Keywords:

Euphorbia esula, glyphosate, latex

\section{Introduction}

Leafy spurge is a perennial weed that infests large areas of the prairie provinces of Canada and the Northern Great Plains of the United States. It is difficult to control with herbicides. Leafy spurge has a system of specialized cells that contain latex and are classified as non-articulated branched laticifers (Raju 1985). The exact function of the laticifer system is not known, but one possible function is for sequestering secondary metabolites (Bonner and Galston 1947). It has been suggested that the laticifer of common milkweed may accumulate herbicides and reduce their effectiveness (Waldecker and Wyse 1985). No data exists to support this hypothesis for leafy spurge. The objective of this study was to determine if leafy spurge laticifers accumulate herbicide.

Glyphosate herbicide was chosen for this experiment because it is not readily metabolized by leafy spurge (Gottrup et al. 1976). Eight uniform greenhouse-grown plants in the vegetative phenological stage were selected. The plants were grown in $10 \times 30$-cm polyvinyl chloride pipes under a 16-hour photoperiod supplemented with a combination of

\footnotetext{
${ }^{1}$ Received 19 June 1986, accepted 16 Oct. 1986.
} 
fluorescent and incandescent lamps. The day/night temperature was $20 \pm 40^{\circ} \mathrm{C}$. Methyllabeled ${ }^{14} \mathrm{C}$-glyphosate (specific activity $1.97 \mathrm{mCi} \mathrm{mmol}^{-1}$ ) was mixed with an equimolar amount of isopropylamine and $0.25 \%$ Mon0818 surfactant. Three leaves on each plant, two-thirds of the way up the stem were treated with a total of $10 \mu \mathrm{L}$ containing $0.52 \mu \mathrm{Ci}$ ${ }^{14}$ C-glyphosate.

Five days after treatment the treated leaves were removed and the ${ }^{14} \mathrm{C}$ remaining on the treated leaf surface was determined as previously described (Maxwell et al. 1987). Radioactivity was measured by liquid scintillation spectroscopy. At 5, 15 and 30 days after treatment latex was collected in capillary tubes by nicking the stem in several locations and collecting the first and subsequent latex drops exuded by the plant separately. The first drop was assumed to contain phloem plus latex exudate while the subsequent drops represented latex alone (Biesboer and Mahlberg 1978). The average volume of latex collected in the first and subsequent drop at 5, 15 and 30 days after treatment was $12 \pm 5$ and $5 \pm 6,16 \pm 6$ and $3 \pm 2$ and $3 \pm 9$ and $3 \pm 2 \mu \mathrm{L}$, respectively. The experimental design was completely random and the experiment was repeated once with qualitatively similar results.

Treated leafy spurge plants absorbed $68 \pm 1.4 \%$ of the applied radioactivity after 5 days. This compares favorably with $89 \%$ absorption of ${ }^{14} \mathrm{C}$-glyphosate by greenhousegrown leafy spurge plants maintained for 7 days at high relative humidity (Gottrup et al. 1976).

Low levels of radioactivity were detected in the phloem plus latex 5 days after treatment and radioactivity increased thereafter (Table 1). There was no detectable radioactivity in the latex 5 days after treatment. Levels of radioactivity were significantly higher 15 days and 30 days after treatment. Waldecker and Wyse (1985) reported that laticifer cells of common milkweed do not accumulate glyphosate. However, their conclusion was based on limited detection of $0.72 \mathrm{dpm} \mu \mathrm{L}^{-1}$ of ${ }^{14} \mathrm{C}$ in the phloem plus latex only 3 days after ${ }^{14} \mathrm{C}$-glyphosate application. The difference between results reported here and those of Waldecker and Wyse (1985) could be due to species differences or more likely, a longer time period is required for movement of radioactivity in amounts sufficient for detection than was used by Waldecker and Wyse (1985) (Table 1). Our results indicate that the laticifer system of leafy spurge accumulates glyphosate or its metabolites.

The radioactive glyphosate was a gift from Monsanto Agricultural Products Company.

Table 1. The accumulation of ${ }^{14} \mathrm{C}$ in the laticifer system of leafy spurge.

\begin{tabular}{lcc}
\hline Days after application & $\begin{array}{c}\text { Phloem and latex } \\
\left(\mathrm{dpm} \mu \mathrm{L}^{-1}\right)\end{array}$ & $\begin{array}{c}\text { Latex } \\
\left(\mathrm{dpm} \mu \mathrm{L}^{-1}\right)\end{array}$ \\
\hline 5 & 0.1 & 0 \\
15 & 2.4 & 8.2 \\
30 & 1.9 & 5.5 \\
$\mathrm{SE}$ & 0.2 & 1.85 \\
\hline
\end{tabular}




\section{Literature cited}

Biesboer, D. D. and Mahlberg, P. G. 1978. Accumulation of nonutilizable starch in laticifers of Euphorbia heterophylla and E. myrsinites. Planta 143:5-10.

Bonner, J. and Galston, W. W. 1947. The physiology and biochemistry of rubber formation in plants. Bot. Rev. 13:543-566.

Gottrup, O., O’Sullivan, P. A., Schraa, R. J. and Vanden Born, W. H. 1976. Uptake, translocation, metabolism, and selectivity of glyphosate in Canadian thistle and leafy spurge. Weed Res. 16:197-201.

Maxwell, B. D., Foley, M. E. and Fay, P. K. 1987. The influence of glyphosate on bud dormancy in leafy spurge (Euphorbia esula). Weed Sci. 35:6-10.

Raju, M. V. S. 1985. Morphology and anatomy of leafy spurge. Pages 26-41 in A. K. Watson, ed. Leafy spurge. Weed Sci. Soc. of Am., Champagne, Ill. 104 pp.

Waldecker, M. A. and Wyse, D. L. 1985. Soil moisture effects on glyphosate absorption and translocation in common milkweed (Asclepius syriaca). Weed Sci. 33:299-305. 